\title{
Bone morphogenetic protein 4 accelerates the establishment of bovine trophoblastic cell lines
}

\author{
Yasunori Suzuki, Katsuo Koshi, Kei Imai ${ }^{1}$, Toru Takahashi ${ }^{2}$, Keiichiro Kizaki and \\ Kazuyoshi Hashizume \\ Laboratory of Veterinary Physiology, Iwate University, Morioka, Iwate 020-8550, Japan, ${ }^{1}$ National Livestock Breeding \\ Center, Nishigo-mura, Fukushima 961-8511, Japan and ${ }^{2}$ National Institute of Agrobiological Sciences, Ikenodai 2, \\ Tsukuba, Ibaraki 305-8602, Japan \\ Correspondence should be addressed to K Hashizume; Email: kazuha@iwate-u.ac.jp
}

Y Suzuki and K Koshi contributed equally to this work

Y Suzuki is now at Tokyo Metropolitan Institute of Public Health, Tokyo 169-0073, Japan

\begin{abstract}
Trophoblastic cells play a crucial role in implantation and placentogenesis. A large proportion of the failures of conception in cows occur in the peri-implantation period, which are known as early embryo losses. In exploring this critical phenomenon, trophoblastic cell lines can provide substantial information. Unfortunately, there are few cell lines for this purpose in cattle because of the difficulty of raising successive cell stock in the long term. In this study, 12 new cell lines were established using bone morphogenetic protein 4 (BMP4). BMP4 stimulated embryonic cells to enter the trophoblastic cell lineage but there were no significant differences between intact and BMP4-treated groups. Only one out of 49 embryos developed trophoblastic cells in the intact group. Finally, 12 cell lines were maintained for around 30 passages, and they retained trophoblastic characteristics and expressed bovine trophoblastic genes: placental lactogen, interferon- $\tau$, pregnancy-associated glycoprotein 1 , and prolactin-related protein 1 . Although the gene expression patterns were different among cell lines and depended on the cells, there was no significant relationship between the expression intensities of genes and the treatment dose of BMP4. All of them expressed bovine POU domain class 5 transcription factor 1 and caudal-type homeobox 2. The expression of these genes was confirmed by quantitative RT-PCR and immunohistochemical detection. These results suggest that BMP4 is involved in the raising of trophoblast cell lines from early embryonic cells and the newly developed cell lines can provide different types of bovine trophoblastic cells with different cell lineages. This may constitute a significant new tool for the examination of trophoblastic differentiation.

Reproduction (2011) 142 733-743
\end{abstract}

\section{Introduction}

Trophoblastic cells play a major role in placentogenesis and produce various kinds of biological substances, including cytokines, growth factors, peptides, and steroid hormones (Spencer et al. 2008, Marikawa \& Alarcón 2009, Tsampalas et al. 2010). The physiological functions of trophoblastic cells have been studied; however, their functions have remained unclear because of the lack of definitive information on cell lineages. Trophoblastic cells arise from early embryonic cells, namely, the outerside of the blastomere at the blastocyst stage. They are the first differentiated cells in the embryo and may have the specific potential to act as stem cells. Trophoblastic cells act in the formation of placental villi and direct the exchange of fetal-maternal information. A primitive trophoblastic cell adopts a certain cell lineage for proliferation and differentiation (Hu \& Cross 2010).
In ruminants, a mononucleate trophoblast cell (MNC) may directly differentiate into a binucleate cell (BNC) without cytokinesis and the BNC then fuses with an endometrial epithelial cell to form a trinucleate cell (Nakano et al. 2002, Fléchon et al. 2007, Ullah et al. 2009). This event is the start of implantation in ruminants; during the peri-implantation period, the $\mathrm{MNC}$ and $\mathrm{BNC}$ (or multinucleate) cells produce various molecules for placentogenesis (Spencer et al. 2004). The functions and mechanism of differentiation of these trophoblastic cells are obscure. Suitable trophoblastic cell lines are useful tools to clarify the specificity and complex mechanisms of placental formation in vitro. However, there are few available bovine trophoblastic cell lines. Various new kinds of cell lines will help in improving the understanding of the functions of trophoblastic cell lineages (Talbot et al. 2000, 2008, Shimada et al. 2001, Michael et al. 2006, Hambruch 
et al. 2010). In cattle, trophoblastic cells may have the potential to induce differentiation for different functional features of cells. For example, trophoblastic mononucleate cells have been shown to produce interferon- $\tau$ (IFNT), which is a factor that signals recognition of pregnancy in cattle, the same as in other ruminants (Martal et al. 1979, Imakawa et al. 1987). On the other hand, BNCs produce various molecules - steroid hormones, placental lactogen $(\mathrm{PL}$, also known as $\mathrm{CSH} 1$ ), prolactin-related protein (PRPs), and pregnancy-associated glycoproteins (PAGs), among others (Reimers et al. 1985, Hashizume et al. 2007) - and take a main role in the fetal-maternal interface (Duello et al. 1986). These facts suggest that the establishment of new trophoblast cell lines provide clue as a necessary tools for studying trophoblast cell lineage. Although we have been developing trophoblastic cell lines from early bovine embryos, the efficiency of generation of these cell lines has been limited (Shimada et al. 2001).

Bone morphogenetic protein 4 (BMP4) is a member of the transforming growth factor- $\beta$ (TGFB) superfamily, which consists of multifunctional growth factors that act through specific signaling pathways, the SMAD pathways. BMP4 has been detected in various reproductive tissues including placenta, ovary, pituitary, uterus, primordial germ cell, etc.; it takes a crucial role in the epiblast-derived tissues and placenta with other TGFB superfamily members (Shimasaki et al. 2004). In fact, the protein plays important roles in the development of the early embryo and is a stimulatory factor for trophoblastic cell lineages (Xu et al. 2002, Das et al. 2007, Wu et al. 2008, Hayashi et al. 2010); however, its effects are still unclear (Kobayashi et al. 2008, Zhang et al. 2008). Various factors including BMP4 and transcription factors seem to participate in the differentiation of the trophoblastic cell lineage (Fujiwara et al. 2002, Babaie et al. 2007, Murohashi et al. 2010). These previous reports urged us to examine the roles of BMP4 in the differentiation of early embryonic cells to trophoblastic lineage in cow. In this study, we examined whether BMP4 stimulates raised trophoblastic cell lines in early embryo culture and analyzed the specificity of individual cell lines.

\section{Results}

\section{Production of recombinant bovine BMP4 and its biological activity}

First, bovine BMP4 cDNA was cloned using the fetal membrane on day 26 of gestation. Then, recombinant bovine BMP4 (rbBMP4) was produced using a cell-free protein expression system. Finally, after $0.45 \mathrm{mg}$ purified and refolded BMP4 protein was collected as shown in Fig. 1a, we examined BMP biological activity using C2C12 myoblasts, which was evaluated histochemically on the basis of ALP activity. rbBMP4 $(80 \mathrm{ng} / \mathrm{ml})$
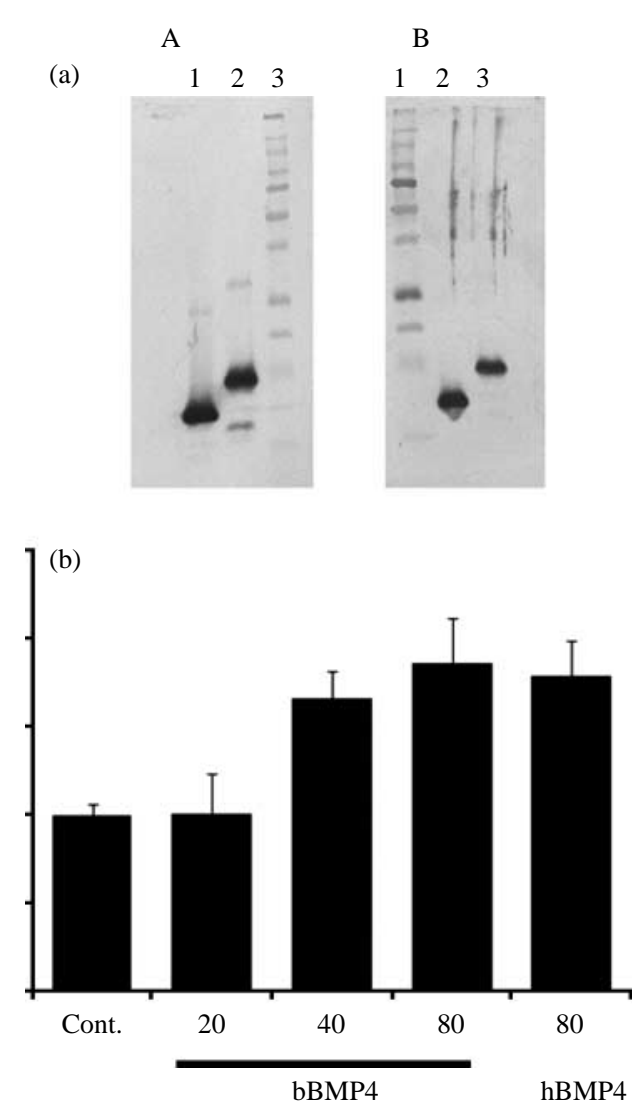

Figure 1 Features and activity of rbBMP4. (a) Western blotting analysis of rbBMP4. Panel A shows results using monoclonal anti-BMP4 antibody. Lane 1: human BMP4, lane 2: bovine BMP4, and lane 3: molecular weight markers. MAB recognized two bands: a major band at $12 \mathrm{kDa}$ and a minor band at $24 \mathrm{kDa}$, in human BMP4. In bovine BMP4, there were three bands: a major band at $14 \mathrm{kDa}$ and minor bands at 29 and $11 \mathrm{kDa}$. Panel B shows polyclonal anti-BMP4 antibody profiles. Lane 1: molecular weight markers, lane 2: human BMP4, and lane 3: bovine BMP4. This antibody recognized components corresponding to 12 and $14 \mathrm{kDa}$ for human and bovine BMP4 respectively. (b) ALP activity of rbBMP4. The assay was repeated three times, and activity is shown as fold change of the value of control $(87.4 \pm 4.8 \mathrm{nmol} \mathrm{pNp} / \mathrm{min}$ per mg BMP4 protein, $n=3)$.

possessed $162.3 \pm 22.5$ (mean \pm s.D., $n=3$ ) ALP activity (nmol $\mathrm{pNp} / \mathrm{min}$ per mg BMP4 protein), which was 1.8fold that of non-BMP4-containing medium as a control $(87.4 \pm 4.8, n=3)$. The ALP activity of rbBMP4 was increased in a dose-dependant manner. The activity was similar to that of human BMP4 (Fig. 1b).

\section{Cell growth}

About ten IVF-derived blastocysts in each group were individually cultured in a well. The culture procedure was repeated four times, and a total of about 40 blastocysts per BMP4 treatment were submitted to the culture for the establishment of cell lines. Then, more than 30 cell clumps were spread out in 2 days after transfer (Table 1) with no significant difference among the BMP4-treated groups, but with the control 
Table 1 Effects of bone morphogenetic protein 4 (BMP4) on the development of trophoblastic cell lines.

\begin{tabular}{|c|c|c|c|c|c|c|c|c|}
\hline \multirow[b]{2}{*}{ BMP4 (ng/ml) } & \multirow[b]{2}{*}{ Attachment (\%) } & \multirow[b]{2}{*}{ Spread (\%) } & \multicolumn{5}{|c|}{ Growing ratio (\%) } & \multirow[b]{2}{*}{ Name of cells } \\
\hline & & & PDL5 & PDL10 & PDL15 & PDL20 & PDL25 & \\
\hline Control (0) & $63.2(31 / 49)$ & $57.1(28 / 49)$ & $57.1(28 / 49)$ & $37.6(18 / 49)$ & $2(1 / 49)$ & $2(1 / 49)$ & $2(1 / 49)$ & BT-D \\
\hline 1 & $85.3(35 / 41)$ & $80.4(33 / 41)$ & $80.4(33 / 41)$ & $46.3(19 / 41)$ & $7.3(3 / 41)$ & $7.3(3 / 41)$ & $7.3(3 / 41)$ & BT-A, BT-E, BT-F \\
\hline 10 & $80.4(33 / 41)$ & $75.6(31 / 41)$ & $75.6(31 / 41)$ & $46.3(19 / 41)$ & $12.2(5 / 41)$ & $7.3(3 / 41)$ & $7.3(3 / 41)$ & BT-B, BT-C, BT-C \\
\hline 100 & $78(32 / 41)$ & $75.6(31 / 41)$ & $75.6(31 / 41)$ & $41.5(17 / 41)$ & $12.2(5 / 41)$ & $12.2(5 / 41)$ & $12.2(5 / 41)$ & $\begin{array}{c}\text { BT-H, BT-I, BT-J, } \\
\text { BT-K, BT-L }\end{array}$ \\
\hline
\end{tabular}

Numbers in parentheses indicate no. of developed embryos/no. of embryos used.

(non-BMP4). The non-BMP4 group exhibited significantly lower rates of both attachment and spread $(P<0.05)$. All spread cell clumps were kept to raise cell lines and the survival rates of cell clumps in all groups were gradually decreased to the 25th passage, which were estimated the same as the population doubling level (PDL) stage. In total, 12 cell lines were raised from the different treatment groups. More cell lines were established in higher dose groups; however, there were no significant differences among the groups, including the control. We named the 12 bovine trophoblastic cell lines as BT-A to BT-L in temporal sequence.

\section{Analysis of gene expression profiles}

The expression of seven specific genes (bovine $\mathrm{CSH} 1$, bovine PRP1, bovine PAG1, bovine IFNT, POU class 5 homeobox 1 (POU5F1), caudal-type homeobox transcription factor $2(C D X 2)$, and $B M P 4)$ were analyzed in 12 new cell lines using quantitative PCR (qPCR; Fig. 2ag). All cell lines expressed POU5F1, CDX2, and BMP4 genes, but the intensity depended on the cell line. There were no significant correlations between the rate of establishing cell lines and the dose of BMP4 or the intensity of BMP4 expression (Table 1 and Fig. 2e). The cell lines were divided into four groups according to the expression of specific genes, CSH1, PRP1, PAG1, and IFNT: group 1: no expression of four trophoblastic cell-specific genes (BT-B); group 2: all four trophoblastic cell-specific genes were expressed (BT-C, BT-E, BT-F, $\mathrm{BT}-\mathrm{H}$, and BT-J); group 3: BNC-specific genes were expressed, namely, CSH1, PRP1, and PAG1, but not IFNT (BT-D, BT-I, BT-K, and BT-L); and group 4: primarily IFNT was expressed (BT-A and BT-G).

\section{Expression of trophoblastic cell-specific proteins}

Bovine trophoblastic cell-specific proteins, $\mathrm{CSH} 1$ and IFNT, were detected by Western blot and/or immunocytochemical methods. Anti-CSH1 antibody clearly detected the protein in eight cell lines, BT-C, BT-D, BT-E, BT-F, BT-I, BT-J, BT-K, and BT-L (Fig. 3a-C and Table 2). IFNT proteins were detected in seven cell lines, BT-A, BT-C, BT-E, BT-F, BT-G, BT-H, and BT-L (Figs 3, 4 and Table 2). $\mathrm{CSH} 1$ protein was found in BNCs and IFNT was found in MNCs. Western blotting data confirmed IFNT expression in most of the cell lines, except for BT-E and BT-G (Fig. 4). These results coincided with the gene expression profiles, except for BT-H, BT-J, and BT-L. POU5F1 and CDX2 protein expressions were examined using the representative cell line, BT-C. POU5F1positive cells were rare at only about 4\% (11/280; positive/examined cells) but about $75 \%$ of cells (209/ 280) expressed CDX2 protein. Some of them produced both proteins simultaneously (Fig. 5).

\section{Discussion}

Trophoblastic cells, MNCs and BNCs, play a crucial role in placental architecture and functions in ruminants; both cells produce a wide range of functional molecules: steroid hormones, IFNT, CSH1, PRPs, PAGs, cathepsins, bovine secreted protein of Ly- 6 domain 1, and cytokines, among others (Reimers et al. 1985, Imakawa et al. 1987, Gross \& Williams 1988, Xie et al. 1991, Matamoros et al. 1994, Martal et al. 1997, Hashizume et al. 2007, Ushizawa et al. 2009). MNC production of IFNT is well known as a factor that signals the recognition of pregnancy; BNCs may play a major role in the establishment of the fetal-maternal interface, namely, BNC fuses with an epithelial cell in endometrium and starts to raise placental villi at around day 20 of gestation (Wooding 1992, Yamada et al. 2002). Although cell lines are a convenient tool to analyze and understand the functions and the mechanisms of trophoblastic cell lineages, few bovine trophoblastic cell lines have been available (Talbot et al. 2000, Shimada et al. 2001). These facts encourage the establishment of new trophoblast cell lines. We have been trying to raise cell lines from early embryo and previously developed a bovine trophoblastic cell line, BT-1. However, the efficiency of raising bovine trophoblastic cell lines is low. In this study, we attempted to improve the efficiency of developing trophoblastic cell lines that have the potential for longterm culture, and to raise various cell lines that have different characteristics in cows.

The cell segregation into trophoblastic cells from embryonic cells at the blastocyst stage is a well-known phenomenon; however, the actual factors responsible are yet to be determined. Various cytokines and transcription factors may be involved; some previous 

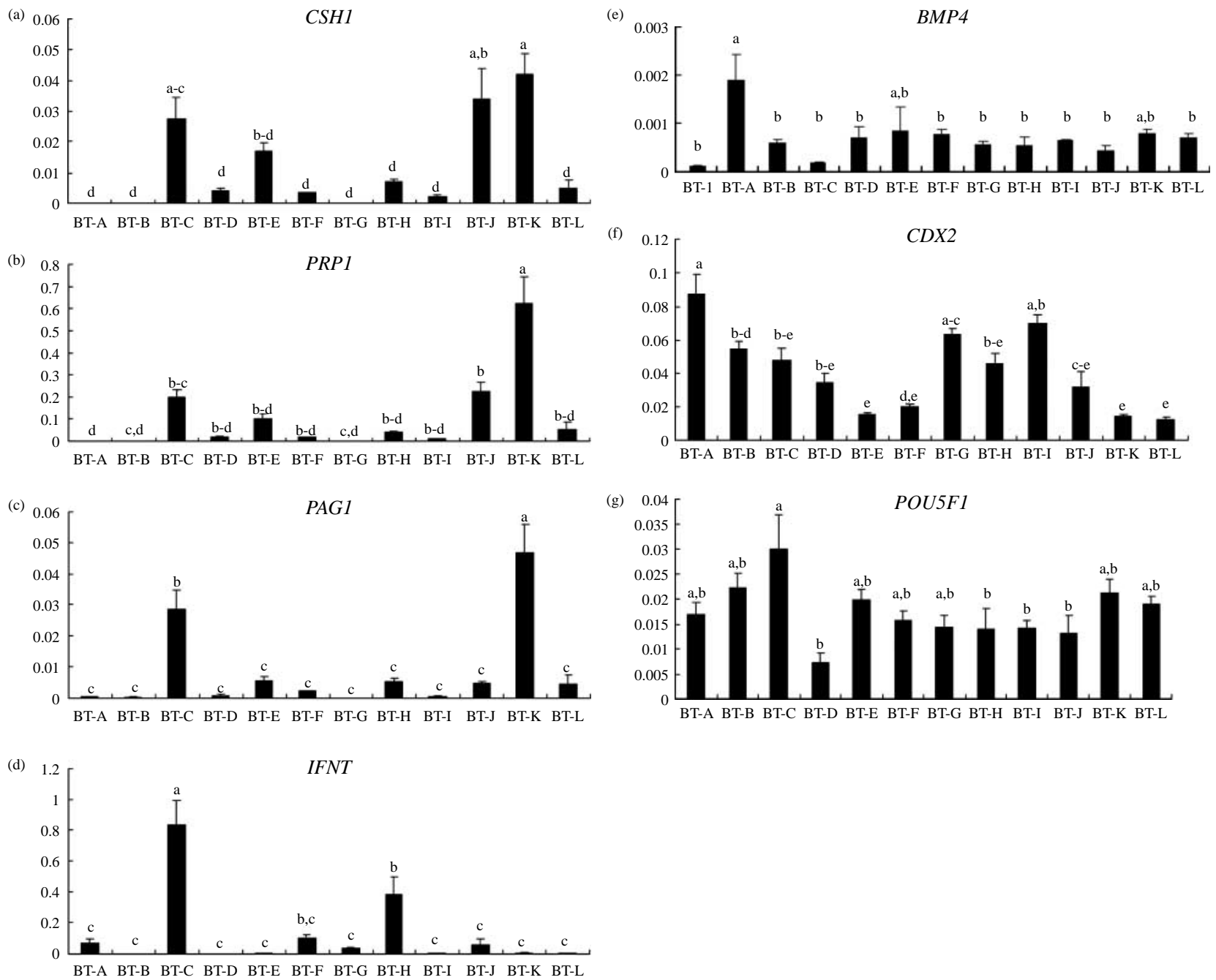

Figure 2 Gene expression profiles in newly developed trophoblastic cell lines. (a) CSH1, (b) PRP1, (c) PAG1, (d) IFNT, (e) BMP4, (f) CDX2, and (g) POU5F1. Data labeled with different letters are significantly different from each other $(P<0.05)$.

reports suggested that the activin/nodal pathway, BMPs, FGF4, FGF2, CDX, and POU5F1 (OCT4) are involved (Pfarrer et al. 2006, Ravelich et al. 2006, Sakurai et al. 2009, Sugawara et al. 2010). In a previous study, we used only conditioned medium from fetal fibroblast cells and succeeded in producing only one cell line from about 50 IVF embryos, which has maintained good growth for over 300 passages (PDL; Shimada et al. 2001, Hashizume et al. 2006). The efficiency was quite low and it generally seems to be difficult to raise trophoblastic cell lines in cattle. In this study, we used BMP4 to raise trophoblastic cell lines because exogenous BMP4stimulated embryonic stem cells (ES) to become trophoblastic cells and promoted trophoblastic cell lines (Kurihara et al. 1993, Murohashi et al. 2010). The addition of BMP4 to culture medium at early embryo stages boosted the establishment of trophoblastic cell lines in bovine, but there was no significant difference between untreated and BMP4 groups. Although mechanisms of enhancing BMP4 production of trophoblastic cells are lacking, some other growth factors/cytokines may be involved in this process because some growth factors play a crucial role for the ES cell lineages (Fujiwara et al. 2002, Das et al. 2007, Wu et al. 2008, Zhang et al. 2008, Hayashi et al. 2010, Murohashi et al. 2010). In this study, we added BMP4 during and after fertilization for 7 days and continuous culture from 6 days. After these treatments of BMP4, no significant effects were found in terms of embryo development, namely, in terms of growth rates up to blastocyst; however, anti-BMP4 antibody suppressed the number of trophoblastic cells on blastocyst (K Imai, T Takahashi, K Kizaki \& K Hashizume, unpublished observations). These results suggest that BMP4 can boost entry into the trophoblastic cell lineage; however, critical periods and doses for treatment of BMP4 to determine cell fate remain to be examined. Although BMP4 may be an induction factor for trophoblastic cell lineages, it is not necessary for the development of trophoblastic cells in mice (Kobayashi et al. 2008, 
(a)
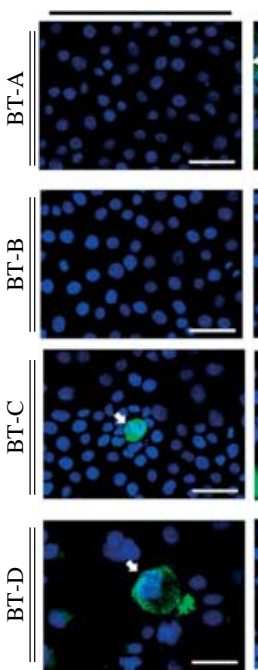
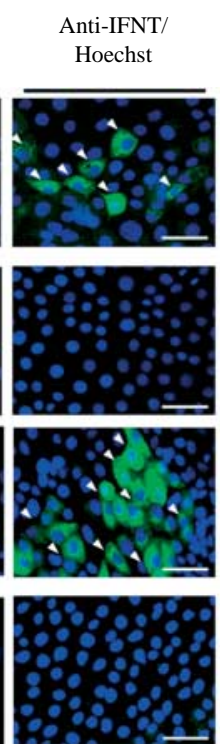
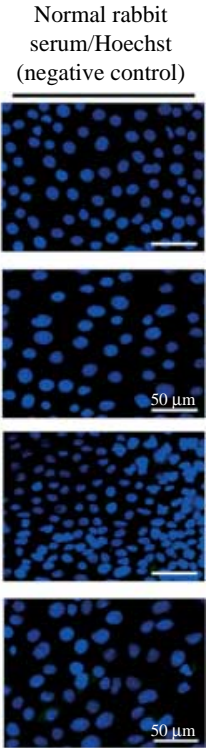

(b)
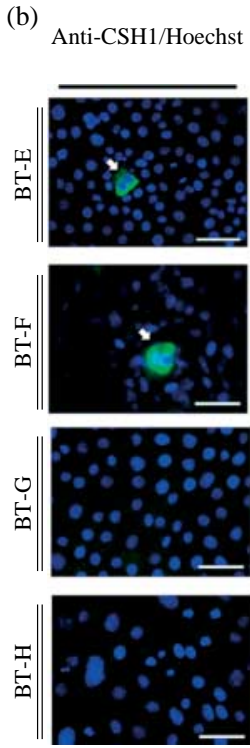

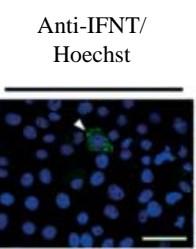

Normal rabbit

serum/Hoechst (negative control)
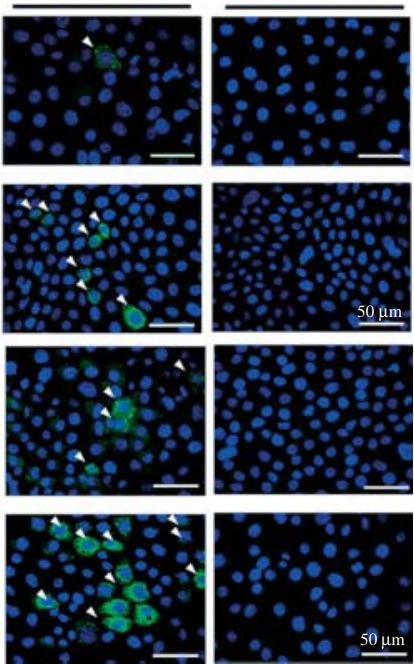

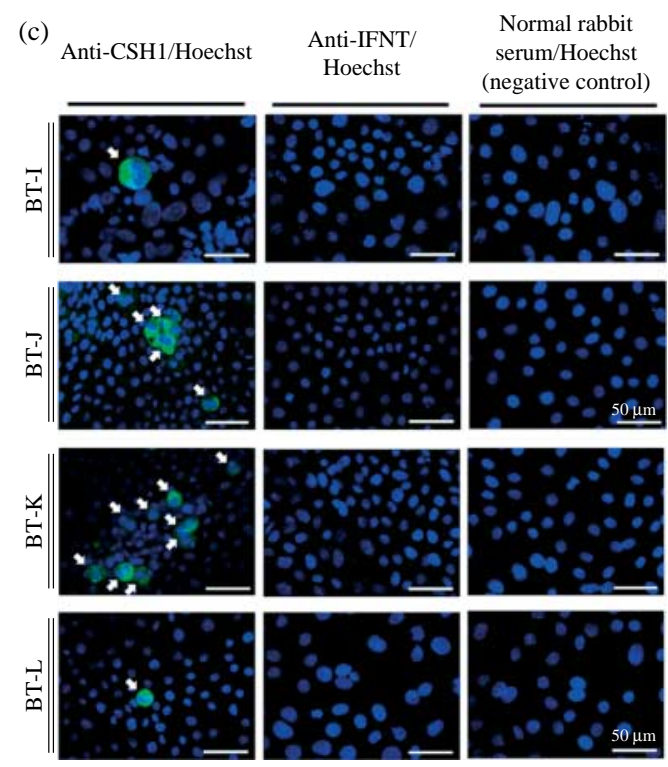

Figure 3 Immunohistochemical detection of placental lactogen (CSH1) and interferon- $\tau$ (IFNT) in different trophoblastic cell lines. (a-c) Arrow indicates CSH1-positive cell, and arrowhead indicates IFNT-positive cell, bar $=50 \mu \mathrm{m}$.

Murohashi et al. 2010). BMP4 combined with some other factors stimulates trophoblastic proliferation and differentiation (Fujiwara et al. 2002, Das et al. 2007, Wu et al. 2008, Hayashi et al. 2010, Murohashi et al. 2010). The other concern for trophoblastic cell lineages from early embryonic cells is that there is a possibility of mixture of epiblast stem cell-like and trophoblast cells; we examined some cell clumps as inner cell mass (ICM) cells, which were condensed and had a dark color under microscopy just after the initiation of culture. The ICMlike cell clumps were eliminated mechanically so they might not be involved as ICM cells. Moreover, even if mixing occurred at an early stage of culture, we think that BMP4 controls the fate of epiblast stem cell-like cells for trophoblastic cells just like hESC and mESC (Xu et al. 2002, Hayashi et al. 2010). Considering this evidence, it is difficult to keep ES-like cells under our culture conditions. The various cell lines raised in this study may be trophoblastic cells and constitute new models for studying the trophoblastic cell lineage in bovine placenta.

It is believed that BNCs are derived from MNCs, but the process and mechanisms of formation are still unclear; a certain type of stem cell forms a BNC without cytokinesis. Another expectation for the raising of BNCs is that cell-cell fusion may form BNCs with retroviral envelope proteins (Black et al. 2010, Koshi et al. 2011). However, these mechanisms are still unclear, and 
Table 2 Number of CSH1-positive and interferon- $\tau$ (IFNT)-positive cells.

\begin{tabular}{lcc}
\hline Cell & CSH1-positive & IFNT-positive \\
\hline BT-A & $0 / 404(0)^{\mathrm{a}}$ & $43 / 264(16.2)$ \\
BT-B & $0 / 544(0)$ & $0 / 626(0)$ \\
BT-C & $3 / 266(1.1)$ & $100 / 301(33.2)$ \\
BT-D & $1 / 225(0.4)$ & $0 / 277(0)$ \\
BT-E & $3 / 470(0.6)$ & $11 / 360(3.1)$ \\
BT-F & $3 / 356(0.8)$ & $21 / 264(8.0)$ \\
BT-G & $0 / 503(0)$ & $19 / 241(7.9)$ \\
BT-H & $0 / 293(0)$ & $88 / 333(26.4)$ \\
BT-I & $5 / 258(1.9)$ & $0 / 330(0)$ \\
BT-J & $14 / 299(4.7)$ & $0 / 381(0)$ \\
BT-K & $26 / 364(7.1)$ & $0 / 314(0)$ \\
BT-L & $10 / 344(2.9)$ & $12 / 376(3.2)$ \\
\hline
\end{tabular}

${ }^{\mathrm{a}}$ No. of immunohistochemical positive cells/no. of counted all cells (\%).

trophoblastic cell lines will provide a suitable model for examining this complex feature. In this study, bunches of bovine trophoblastic cell lines were established and they have different features and comprise at least four types, with specific gene expression profiles of CSH1, PRP1, and IFNT.

CSH1 is a representative marker for mature BNCs, and, in this study, four new cell lines expressed this gene intensively and four (BT-C, BT-E, BT-F, and BT-L) of them expressed IFNT, which is an indicator of MNCs, simultaneously. A similar result was confirmed previously in the cell line BT-1 (Shimada et al. 2001). Cell lines with different features were established, which were classified in terms of protein expression: cell lines that express only BNC-specific genes (BT-D, BT-I, BT-J, and BT-K), cell lines that express only IFNT (BT-A, BT-G, and $\mathrm{BT}-\mathrm{H})$, and a cell line that expresses neither of these features (BT-B). These classifications agreed with gene expressions, but there were some differences. The reason for this is still difficult to identify but protein-based data seem to be reliable.

However, all cell lines established in this study expressed POU5F1 and CDX2 genes, and some cells produced both simultaneously, but not all of them. The mechanisms of expression and involvement of these genes are still poorly understood, but they also have been detected in BT-1 (Hashizume et al. 2006, Sakurai et al. 2009). POU5F1 is well known as a stem cell marker and plays a crucial role in the maintenance of stem cell properties, including pluripotency in ES cells. Although the repression of POU5F1 induced ES into the trophoblastic cell lineage in mice (Niwa et al. 2005, Yuan et al. 2009), these data suggest that the BT cells are involved in stem cell features and are not terminal cells. Another transcription gene, $C D X 2$, regulates the trophoblastic cell lineage (Niwa et al. 2005, Ealy \& Yang 2009, Home et al. 2009), and its importance and regulatory mechanisms in trophoblasts may be similar in many species, including cows. The gene may have other specific roles in bovine trophoblasts because it regulates IFNT, which is a specific marker for trophoblastic mononucleate cells in ruminants (Ezashi et al. 2008,
Cooke et al. 2009, Sakurai et al. 2009). The regulatory mechanism of IFNT expression and transcription still remains to be examined (Bai et al. 2009). CSH1 expression is well correlated to the maturation of $\mathrm{BNCs}$ among bovine trophoblasts (Nakano et al. 2005); however, information on the regulation and transcription factors for $\mathrm{CSH} 1$ is still limited. Some elements, AP2, GATAs, PURA, and SPs, have been reported as activation factors for this gene, and $\mathrm{CSH} 1$ expression was closely related to the implantation process spatiotemporally (Limesand et al. 2004, Ushizawa et al. 2007, Jeckel et al. 2009). GATA may play a regulatory role of $\mathrm{CSH} 1$ expression and differentiation of BNCs (Bai et al. 2011).

In conclusion, we developed 12 bovine trophoblast cell lines, including four with different features, with BMP4 supplementation at the early embryo stage. All cell masses expressed POU5F1 and CDX2 genes, but they expressed MNC-and/or BNC-specific genes in ways that were dependent on the cell line. These cell lines will provide effective and unique models for the study of trophoblastic cell functions and lineages in ruminants.

\section{Materials and Methods}

\section{Production and culture of IVF ova}

Ovaries derived from a local slaughterhouse that were brought to the laboratory (National Livestock Breeding Center: NLBC, Fukushima, Japan) were used for IVF as reported previously (Imai et al. 2006). Briefly, cumulus-oocyte complexes (COCs) after aspiration from small follicles $(2-6 \mathrm{~mm}$ in diameter) were cultured for $21-22 \mathrm{~h}$ in $5 \% \mathrm{CO}_{2}$ at $38.5^{\circ} \mathrm{C}$ in maturation medium: 5\% calf serum (CS, Gibco) containing 25 mM HEPESbuffered TCM-199 with Earle's salt (Gibco), and then covered with paraffin oil (Paraffin Liquid, Nacalai Tesque, Kyoto, Japan) in $35 \mathrm{~mm}$ Petri dishes (Nunc, Roskilde, Denmark) at $38.5^{\circ} \mathrm{C}$ in $5 \% \mathrm{CO}_{2}$ in air with saturated humidity. After maturation culture, COCs were mixed with capacitated spermatozoa $\left(3 \times 10^{6} / \mathrm{ml}\right)$ and cultured for $6 \mathrm{~h}$ in BO solution containing
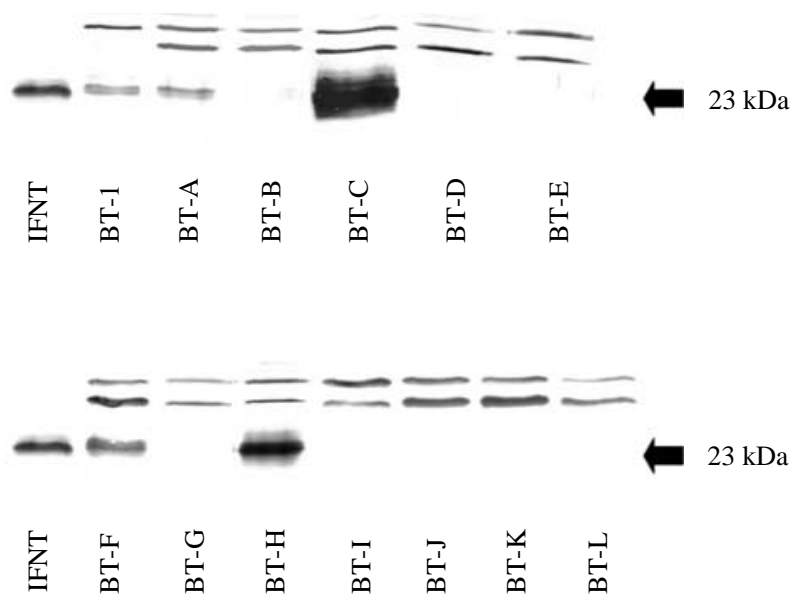

Figure 4 Western blotting analysis of interferon- $\tau$ in different trophoblastic cell lines. Recombinant interferon- $\tau$ was used as a positive indicator for protein. Arrow indicates a molecular weight of $23 \mathrm{kDa}$. 
Hoechst 33342

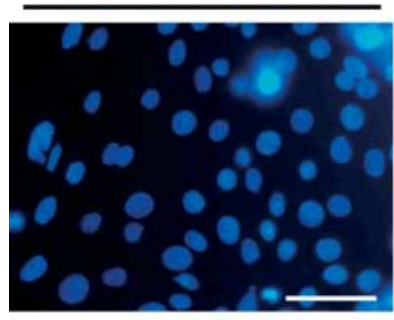

Anti-CDX2
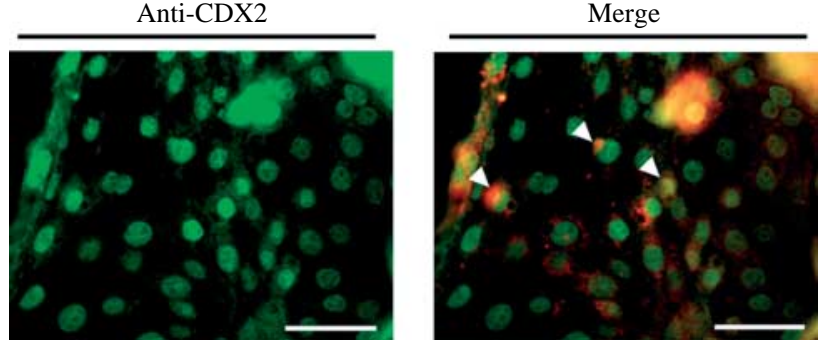

Figure 5 Immunocytochemical detection of CDX2 and POU5F1. In this examination, BT-C cell line was used. Arrowhead indicates POU5F1and CDX2-positive cell, bar $=50 \mu \mathrm{m}$.

$2 \mathrm{U} / \mathrm{ml}$ heparin (Novo-Heparin Injection 1000, Aventis Pharma Ltd., Tokyo, Japan), $5 \mathrm{mM}$ hypotaurine (Sigma), and $10 \mathrm{mg} / \mathrm{ml}$ BSA (crystallized and lyophilized, Sigma) at $38.5{ }^{\circ} \mathrm{C}$ in $5 \% \mathrm{CO}_{2}$ in air with saturated humidity. After removal of cumulus cells, putative zygotes were cultured in CR1aa medium containing $5 \%$ CS with or without recombinant BMP4 (raised by TT) at $38.5^{\circ} \mathrm{C}$ in $5 \% \mathrm{CO}_{2}$ in air with saturated humidity for 7 days. Then, blastocysts were moved into TCM-199 medium containing 20\% fetal bovine serum (FBS, Gibco), $100 \mathrm{mM}$ $\beta$-mercaptoethanol (2-mercaptoethanol, Sigma) with or without BMP4, and cultured for 6 days at $38.5{ }^{\circ} \mathrm{C}$ in $5 \% \mathrm{CO}_{2}$ in air with saturated humidity. Three different concentrations of BMP4 were used: 1, 10, and $100 \mathrm{ng} / \mathrm{ml}$. All animal experiments were individually approved by the Animal Experimental Committee of Iwate University and NBLC.

\section{Raising of rbBMP4 and anti-BMP4 antibody}

rbBMP4 was produced using a cell-free protein expression system (Rapid Translation System, Roche Applied Science). In brief, bovine BMP4 cDNA was cloned using a forward primer: ATTATTAAGCGGCCGCCGTAGCCCCAAGCATCACCCACAG and a reverse primer: ATCCTCGGATCCTCAGCGGCACCCACATCCCTCCAC, from the fetal membrane on day 26 of gestation, and put into an expression vector (pIVEX 2.4d, Roche), which was digested with Notl/BamHI, ligated with T4 ligase (Promega). It was transformed into Escherichia coli XL-1 Blue Supercompetent cells (Stratagene, La Jolla, CA, USA). The ampicillin-resistant transformants were selected and subcultured with LB broth in the presence of ampicillin. Plasmids were isolated from the culture with centrifugal kit (Mini Prep kit, Qiagen). A plasmid containing the mature protein region of BMP4 with correct nucleotide sequence was used as a template for cell-free protein expression.
The rbBMP4 was produced with the above cell-free protein expression system with RTS500 Proteomaster E. coli HY kit (Roche) according to the manufacturer's instructions. During the expression, BMP4 formed an insoluble precipitate in the reaction mixture. After $24 \mathrm{~h}$ of expression, the reaction mixture was centrifuged at $22500 \mathrm{~g}$ for $15 \mathrm{~min}$ at $4{ }^{\circ} \mathrm{C}$. The pellet was dissolved with $5 \mathrm{ml}$ binding buffer (0.1 M PBS, $0.3 \mathrm{M} \mathrm{NaCl}, 0.02 \mathrm{M}$ imidazole, $6 \mathrm{M}$ urea, $\mathrm{pH} 8.0$ ), centrifuged at the same conditions as above and the supernatant was incubated with $2 \mathrm{ml}$ Ni-Sepharose (GE Healthcare UK Ltd., Little Chalfont, UK) at $4{ }^{\circ} \mathrm{C}$ overnight. Then, it was applied to a disposable column (Bio-Rad). The column was extensively washed with binding buffer to remove unbound proteins. rbBMP4 was eluted with elution buffer (0.1 M PBS, 0.3 M NaCl, 0.5 M imidazole, $6 \mathrm{M}$ urea, $\mathrm{pH}$ 8.0). The presence of rbBMP4 in each fraction was determined by western blot analysis with anti-His antibody (Bethyl, Montgomery, TX, USA) because pIVEX $2.4 \mathrm{~d}$ expression vector resulted in the inclusion of $6 \times$ His epitope tag at the amino terminal of the recombinant protein. Immunopositive fractions were pooled, utilized for immunization to generate anti-rbBMP4 antibody in rabbits, and some portion was subjected to renaturation. The rbBMP4 was refolded by sequential dialysis with gradual decrease in urea. First, the sample was dialyzed against $0.1 \mathrm{M}$ PBS $(\mathrm{pH} 7.2)$ supplemented with $0.1 \mathrm{M} \mathrm{NaCl}$ and $3 \mathrm{M}$ urea overnight at $4{ }^{\circ} \mathrm{C}$ using a dialysis cassette (Float-a-Lizer, NMCO 8K, Spectrum, Rancho Dominguez, CA, USA), then further dialyzed against 0.1 M PBS ( $\mathrm{pH}$ 7.2) supplemented with $0.1 \mathrm{M} \mathrm{NaCl}, 2 \mathrm{M}$ urea, and $0.4 \mathrm{M}$ arginine overnight at $4{ }^{\circ} \mathrm{C}$ using the same dialysis cassette. From this point forward, the sample was sequentially dialyzed overnight at $4{ }^{\circ} \mathrm{C}$ with gradual decreasing concentration of urea $(2.0,1.0,0.5$, and $0 \mathrm{M}$ ) in the presence of $0.4 \mathrm{M}$ arginine. Finally, the sample was dialyzed against the same PBS without urea and arginine. The dialyzed solutions were concentrated in a centrifugal column (MWCO 10K, Amicon, Millipore, Bedford, CA, USA). The protein concentration of the purified product was measured by Bradford dye-binding procedure. The presence of target protein was determined by SDS-PAGE and western blotting with anti-BMP4 antibody (either polyclonal (raised using rbBMP4) or monoclonal anti-human BMP4 antibody (Santa Cruz Biotechnology, Santa Cruz, CA, USA, BMP4 (3H2.3) sc-12721)). Anti-rbBMP4 antibody generation was performed by Qiagen. Briefly, adult Japanese White rabbits were used for immunization. Rabbits were bled before immunization to collect preimmuno-serum. For primary immunization, $0.2 \mathrm{mg}$ rbBMP4 was injected intradermally into the rabbit with Freund's complete adjuvant. Quintuple booster immunizations with $0.2 \mathrm{mg}$ antigen and incomplete adjuvant were given s.c. every 2 weeks following the initial injection. Animals were bled a week after second and fourth booster injections to determine titers. The titer of antiserum was determined by ELISA as previously reported (Takahashi et al. 2004). A week after final booster injection, rabbits were exsanguinated under deep anesthesia. Harvested serum was stored at $-30{ }^{\circ} \mathrm{C}$ until use. Generated antiserum was used at 1:1000 dilution for western blotting. 
Table 3 RT-PCR primers.

\begin{tabular}{|c|c|c|c|c|c|}
\hline Gene names & $\begin{array}{c}\text { Annealing } \\
\text { temperature }\left({ }^{\circ} \mathrm{C}\right)\end{array}$ & $\begin{array}{c}\text { Cycle } \\
\text { number }\end{array}$ & Accession no. & Primers & Product \\
\hline \multirow[t]{2}{*}{ GAPDH } & \multirow[t]{2}{*}{60} & \multirow[t]{2}{*}{30} & \multirow[t]{2}{*}{ NM_001034034.1 } & Forward: CСТTCATTGACСТTСАСТАСАTGGTCTA & $173-200$ \\
\hline & & & & Reverse: GCTGTAGCCAAATTCATTGTCGTACCA & $1029-1003$ \\
\hline \multirow[t]{2}{*}{$\mathrm{CSH} 1$} & \multirow[t]{2}{*}{60} & \multirow[t]{2}{*}{35} & \multirow[t]{2}{*}{ NM_181007.2 } & Forward: CCATCTCCCCATCAGCAGCAGT & $105-126$ \\
\hline & & & & Reverse: GAGACCCATTACACCСAAACAT & $975-954$ \\
\hline \multirow[t]{2}{*}{ PRP1 } & \multirow[t]{2}{*}{60} & \multirow[t]{2}{*}{35} & \multirow[t]{2}{*}{ NM_174159.2 } & Forward: CACGGTCAACAGGAGTCCTCACC & $43-65$ \\
\hline & & & & Reverse: AATTTCAGGTAGCCCGCTGTGG & $873-852$ \\
\hline \multirow[t]{2}{*}{ PAG1 } & \multirow[t]{2}{*}{60} & \multirow[t]{2}{*}{35} & \multirow[t]{2}{*}{ NM_174411.2 } & Forward: CACCATTGGAACACCCCC & $245-262$ \\
\hline & & & & Reverse: CACTGGGTAGTTGATGCCGTT & 989-969 \\
\hline \multirow[t]{2}{*}{ IFNT } & \multirow[t]{2}{*}{58} & \multirow[t]{2}{*}{30} & \multirow[t]{2}{*}{ NM_001015511.2 } & Forward: TCCCCATGGCCTTCGTGCTCTCTCT & 75-99 \\
\hline & & & & Reverse: CTCAAAGTGAGTTCAGATCTCCACC & $668-644$ \\
\hline \multirow[t]{2}{*}{ POU5F1 } & \multirow[t]{2}{*}{58} & \multirow[t]{2}{*}{30} & \multirow[t]{2}{*}{ NM_174580.2 } & Forward: GGTTCTCTTTGGAAAGGTGTTC & $516-537$ \\
\hline & & & & Reverse: ACACTCGGACCACGTCTTTC & $829-810$ \\
\hline \multirow[t]{2}{*}{$C D \times 2$} & \multirow[t]{2}{*}{60} & \multirow[t]{2}{*}{30} & \multirow[t]{2}{*}{ XM_871005.3 } & Forward: TATCACCATCCGGAGGAAAG & $778-797$ \\
\hline & & & & Reverse: GCTCAGCCTGGAATTGCTAC & 1105-1086 \\
\hline \multirow[t]{2}{*}{ BMP4 } & \multirow[t]{2}{*}{60} & \multirow[t]{2}{*}{35} & \multirow[t]{2}{*}{ NM_001045877.1 } & Forward: CGTAGCCCCAAGCATCACCCACAG & 1075-1098 \\
\hline & & & & Reverse: TCAGCGGCACCCACATCCCTCCAC & 1428-1405 \\
\hline
\end{tabular}

\section{Assay for BMP4 biological activity}

Refolded rbBMP4 was used for cell culture experiments. The biological activity of recombinant BMP4 was determined by ALP assay using the mouse myoblast cell line, C2C12. The cells were purchased from Riken Cell Bank (Tsukuba, Ibaraki, Japan). C2C12 cells were maintained in DMEM (Sigma) containing $100 \mathrm{IU} / \mathrm{ml}$ penicillin and $100 \mu \mathrm{g} / \mathrm{ml}$ streptomycin (Sigma) supplemented with 15\% FBS (HANA-NESCO, Tokyo, Japan; growth medium) at $37^{\circ} \mathrm{C}$ in a humidified atmosphere of $5 \% \mathrm{CO}_{2}$ in air. The growth medium was replaced on day 1 with DMEM containing 5\% FBS with various concentrations of recombinant BMP4. ALP bioassay was performed following previous reports (Katagiri et al. 1994, Kirsch et al. 2000) with some modification; in brief, $\mathrm{C} 2 \mathrm{C} 12$ cells were stimulated at a density of $1.3 \times 10^{5}$ cells/well in a six-well plate for $120 \mathrm{~h}$ with either $20-80 \mathrm{ng} / \mathrm{ml}$ bovine recombinant BMP4 or human BMP4 (Sigma). Non-BMP4-containing culture medium was used for a control. Then, cells were washed with $0.9 \% \mathrm{NaCl}$ and lysed with $200 \mu \mathrm{l}$ of lysis buffer ( $1 \% \mathrm{NP}-40,0.9 \% \mathrm{NaCl}$ ). ALP activity in the cell lysate was assayed at $37^{\circ} \mathrm{C}$ in the buffer containing $0.2 \mathrm{M}$ 2-amino-2-methyl-I-propanol and $1 \mathrm{mM}$ $\mathrm{MgCl}_{2}, \mathrm{pH}$ 9.5, for 30 min using $p$-nitrophenylphosphate as a substrate. The enzyme activity was expressed as nanomoles of $p$-nitrophenol produced per min per mg protein. The diluent of protein content was determined using the Bio-Rad Quick Start kit (Bio-Rad) using BSA as the standard. The rbBMP4 exhibited bioactivity the same as human BMP4 (Fig. 1b).

\section{Nursing cell culture}

After examining the absence of an ICM-like cell clump by microscopy, spherical cell bodies were transferred into collagen-coated (Cellmatrix Type I-C, Nitta Gelatin, Osaka, Japan) 24-well culture plates (BM, Tokyo, Japan), individually. Each cell body was cultured in ESM-2 medium ( $\alpha$ MEM including $8.9 \mu \mathrm{g} / \mathrm{ml}$ L-alanine, $13.2 \mu \mathrm{g} / \mathrm{ml}$ L-asparagine, $13.3 \mu \mathrm{g} / \mathrm{ml}$ L-aspartic acid, $14.7 \mu \mathrm{g} / \mathrm{ml}$ L-glutamic acid, $7.5 \mu \mathrm{g} / \mathrm{ml}$ glycine, $11.5 \mu \mathrm{g} / \mathrm{ml}$ L-proline, and $10.5 \mu \mathrm{g} / \mathrm{ml}$ L-serine, $+100 \mu \mathrm{M} 2 \beta$-mercaptoethanol $+5 \mu \mathrm{g} / \mathrm{ml}$ insulin $+10 \mathrm{ng} / \mathrm{ml}$ EGF $+10 \mathrm{ng} / \mathrm{ml}$ FGF $-1+10 \mu \mathrm{g} / \mathrm{ml}$ heparin $+5 \mathrm{mg} / \mathrm{ml}$ BSA; Research Institute for Functional Peptides, Yamagata, Japan) containing 20\% FBS until cells made contact and spread out over the whole well at $37{ }^{\circ} \mathrm{C}$ in $5 \% \mathrm{CO}_{2}$. Close to confluence, cells were scaled out and half of them were

Table 4 Quantitative RT-PCR primers.

\begin{tabular}{|c|c|c|c|}
\hline Gene names & Accession no. & Primers & Product \\
\hline \multirow[t]{2}{*}{ GAPDH } & \multirow[t]{2}{*}{ NM_001034034.1 } & Forward: AAGGCCATCACCATCTTCCA & 280-299 \\
\hline & & Reverse: CCACCACATACTCAGCACCAGCAT & $355-332$ \\
\hline \multirow{2}{*}{$\mathrm{CSH} 1$} & \multirow{2}{*}{ NM_181007.2 } & Forward: TGCCACACCGAATTCATGAC & $447-466$ \\
\hline & & Reverse: AGGGCTTCGTCСТСТGTATTTG & 514-493 \\
\hline \multirow[t]{2}{*}{ PRP1 } & \multirow[t]{2}{*}{ NM_174159.2 } & Forward: CACGGAGCTGCAGCATATGA & $501-520$ \\
\hline & & Reverse: CCTTGTGGCGCTTGATAGGA & $558-539$ \\
\hline \multirow[t]{2}{*}{ PAG1 } & \multirow[t]{2}{*}{ NM_174411.2 } & Forward: TCCACTTTCCGGCTTACCAA & $375-394$ \\
\hline & & Reverse: ССТTTCATTCTCССАGАTCСАT & $436-415$ \\
\hline \multirow[t]{2}{*}{ IFNT } & \multirow[t]{2}{*}{ NM_001015511.2 } & Forward: CTAGGTGCCAGGCAGAACCT & 173-192 \\
\hline & & Reverse: GGGATGAGGAGAGAGTCTGTTCA & $232-210$ \\
\hline \multirow[t]{2}{*}{ POU5F1 } & \multirow[t]{2}{*}{ NM_174580.2 } & Forward: AGGAAGCTGACAACAACGAGAAT & $626-648$ \\
\hline & & Reverse: GGCCTGCACAAGGGTCTCT & $687-696$ \\
\hline \multirow[t]{2}{*}{$C D \times 2$} & \multirow{2}{*}{ XM_871005.3 } & Forward: CAGAACCGCAGAGCAAAGG & $851-869$ \\
\hline & & Reverse: GTTGCTGCTGCTGTTGCAA & $911-893$ \\
\hline \multirow[t]{2}{*}{ BMP4 } & \multirow[t]{2}{*}{ NM_001045877.1 } & Forward: CTGTCAATTCCAGTATCCCCAAA & $1289-1311$ \\
\hline & & Reverse: TGGAGATGGCGCTGAGTTC & $1348-1330$ \\
\hline
\end{tabular}


transferred into a new collagen-coated 24-well culture plate with DMEM (Sigma)/Nutrient Mixture F12 Ham (F12, Sigma) medium that contained $10 \% \mathrm{FBS}, 100 \mu \mathrm{g} / \mathrm{ml}$ streptomycin, and $100 \mathrm{U} / \mathrm{ml}$ penicillin (Sigma) at $37{ }^{\circ} \mathrm{C}$ in $5 \% \mathrm{CO}_{2}$. Then, the cells were maintained in the same medium and under the same culture conditions as in the previous cell culture method (Shimada et al. 2001). The estimation of cell lineage was decided using the PDL following Hayflick's formula with the starting cell number estimated as 3000 at the spherical cell body stage. The estimation followed the ATTC protocol in terms of a formula for use for the calculation of population doubling as follows: $n=3.32(\log$ UCY $-\log I)+X$, where $n=$ the final PDL number at the end of a given subculture, $U C Y=$ the cell yield at that point, $I=$ the cell number used as inoculum to begin that subculture, and $X=$ the doubling level of the inoculum used to initiate the subculture being quantitated (ATCC http://www.atcc.org/CulturesandProducts/TechnicalSupport/FrequentlyAskedQuestions/tabid/469/Default.aspx).

In this study, 15- to 25-passage (the same as PDL) cells were used for gene expression, biochemical, and cytochemical analyses.

\section{Conventional and quantitative RT-PCR}

After removal of culture medium, $1 \mathrm{ml}$ TRIzol reagent (Invitrogen) was added to a $25 \mathrm{~cm}^{2}$ culture bottle (BM) and total RNA was extracted following the manufacturer's instructions. The quality of RNA was confirmed by agarose gel electropheresis with no degradation of $28 \mathrm{~S}$ and $18 \mathrm{~S}$ RNA. The amounts of RNA were measured using Nano Drop (Nano Drop Technologies, Wilmington, DE, USA). Gene expressions and sequences were analyzed as described in previous reports. In brief, conventional RT-PCR was performed by primer sets (Table 3) and amplified with AmpliTaq Gold (Applied Biosystems, Carlsbad, CA, USA). PCR products were subcloned into pGEM-T Easy Vector Systems in accordance with the manufacturer's instructions and the sequences of cloned plasmids were analyzed with ABI PRISMR 3100-Avant Genetic Analyzer (Applied Biosystems). The gene expression intensity was determined by quantitative RT-PCR using SYBR Green PCR Master Mix (ABI) and ABI7300 (Applied Biosystems) following a previous report. The primer sets for $G A P D H, C S H 1, P R P 1$, PAG1, IFNT, BMP4, POU5F1, and CDX2 were used as shown in Table 4. The amount of expression was estimated using a cloned template of each gene.

\section{Western blotting}

Cells close to confluence were collected from the $25 \mathrm{~cm}^{2}$ bottle with a cell scraper (Greiner Bio-One Japan, Tokyo, Japan) using the following procedure. First, cells were washed with DMEM/F12 medium without FBS three times and were cultured for $2 \mathrm{~h}$ with DMEM/F12 medium without FBS at $37^{\circ} \mathrm{C}$. The medium was replaced with $2 \mathrm{ml}$ fresh DMEM/F12 medium and cells were cultured for $48 \mathrm{~h}$ at $37{ }^{\circ} \mathrm{C}$ in $5 \% \mathrm{CO}_{2}$. Then, culture medium was transferred into a tube and centrifuged at $3000 \mathrm{~g}$ for $10 \mathrm{~min}$; supernatants were then collected for western blotting. The proteins in the collected media were precipitated with a fourfold volume of acetone
(Sigma). The precipitates were dissolved in PBS, $\mathrm{pH} 7.4$, and loaded with loading buffer for SDS-PAGE in $2 \mu \mathrm{g} / 20 \mu$ l protein per lane. After separation, proteins were transferred onto PVDF membrane (Immobilon-P, Millipore, Billerica, MA, USA) with semi-dry blotter (Bio-Rad Japan). The transferred membranes were detected with anti-IFNT $(\times 2000)$ antisera as described in previous reports (Shimada et al. 2001, Nakano et al. 2002).

\section{Immunocytochemistry}

Trophoblast cells were cultured on collagen-coated cover slips. After cells proliferated close to confluence, the slips were fixed in $4 \%$ paraformaldehyde in $0.1 \mathrm{M}$ PBS, $\mathrm{pH} 7.4$, at $4{ }^{\circ} \mathrm{C}$ for $15 \mathrm{~min}$. The cell slips were incubated with one of the following solutions: anti-IFNT (X1000), anti-CSH1 (X1000), antiPOU5F1 (Santa Cruz Biotechnology, $\times 500$ ), CDX2 (Santa Cruz Biotechnology, $\times 500$ ), and rabbit IgG for $2 \mathrm{~h}$ at room temperature; after washing with PBS, the slips were incubated with secondary antibody: Alexa Fluor 488 donkey anti-rabbit IgG (Invitrogen) at a dilution of 1:500 in PBS containing 1\% BSA, $0.05 \% \mathrm{NaN}_{3}$, and $0.3 \%$ Triton X-100. Slips were stained with Hoechst $33342(5 \mu \mathrm{g} / \mathrm{ml}$, Invitrogen $)$ in secondary antibody solution. Then, each protein expression was detected with ECLIPSE E600 (Nikon, Tokyo, Japan), individually. Detailed detection procedures were in accordance with previous reports (Shimada et al. 2001, Hashizume et al. 2006).

\section{Statistical analysis}

Differences in established cell numbers were analyzed by $\chi^{2}$ test. The gene expression data were analyzed initially by ANOVA and followed by Tukey-Kramer multiple comparison test using JMP software (SAS Institute, Inc., Cary, NC, USA). $P$ values of $<0.05$ were considered significant.

\section{Declaration of interest}

The authors declare that there is no conflict of interest that could be perceived as prejudicing the impartiality of the research reported.

\section{Funding}

This work was supported by a grant (Kiban-kenkyu B 20380159) from the Ministry of Education, Culture, Sport, Science, and Technology of Japan, and also by a grant-in-aid from the Research Project for Utilizing Advanced Technologies (05-1770) from the Ministry of Agriculture, Forestry and Fisheries of Japan.

\section{References}

Babaie Y, Herwig R, Greber B, Brink TC, Wruck W, Groth D, Lehrach H, Burdon T \& Adjaye J 2007 Analysis of Oct4-dependent transcriptional networks regulating self-renewal and pluripotency in human embryonic stem cells. Stem Cells 25 500-510. (doi:10.1634/ stemcells.2006-0426)

Bai H, Sakurai T, Kim MS, Muroi Y, Ideta A, Aoyagi Y, Nakajima $\mathbf{H}_{\text {, }}$ Takahashi M, Nagaoka K \& Imakawa K 2009 Involvement of GATA 
transcription factors in the regulation of endogenous bovine interferontau gene transcription. Molecular Reproduction and Development $\mathbf{7 6}$ 1143-1152. (doi:10.1002/mrd.21082)

Bai H, Sakurai T, Someya Y, Konno T, Ideta A, Aoyagi Y \& Imakawa K 2011 Regulation of trophoblast-specific factors by GATA2 and GATA3 in bovine trophoblast CT-1 cells. Journal of Reproduction \& Development 57 518-525. (doi:10.1262/jrd.10-186K)

Black SG, Arnaud F, Burghardt RC, Satterfield MC, Fleming JA, Long CR, Hanna C, Murphy L, Biek R, Palmarini M et al. 2010 Viral particles of endogenous betaretroviruses are released in the sheep uterus and infect the conceptus trophectoderm in a transspecies embryo transfer model. Journal of Virology 84 9078-9085. (doi:10.1128/JVI. 00950-10)

Cooke FN, Pennington KA, Yang Q \& Ealy AD 2009 Several fibroblast growth factors are expressed during pre-attachment bovine conceptus development and regulate interferon-tau expression from trophectoderm. Reproduction 137 259-269. (doi:10.1530/REP-08-0396)

Das P, Ezashi T, Schulz LC, Westfall SD, Livingston KA \& Roberts RM 2007 Effects of fgf2 and oxygen in the bmp4-driven differentiation of trophoblast from human embryonic stem cells. Stem Cell Research 1 61-74. (doi:10.1016/j.scr.2007.09.004)

Duello TM, Byatt JC \& Bremel RD 1986 Immunohistochemical localization of placental lactogen in binucleate cells of bovine placentomes. Endocrinology 119 1351-1355. (doi:10.1210/endo-119-3-1351)

Ealy AD \& Yang QE 2009 Control of interferon-tau expression during early pregnancy in ruminants. American Journal of Reproductive Immunology 61 95-106. (doi:10.1111/j.1600-0897.2008.00673.x)

Ezashi T, Das P, Gupta R, Walker A \& Roberts RM 2008 The role of homeobox protein distal-less 3 and its interaction with ETS2 in regulating bovine interferon-tau gene expression-synergistic transcriptional activation with ETS2. Biology of Reproduction 79 115-124. (doi:10.1095/ biolreprod.107.066647)

Fléchon JE, Fléchon B, Degrouard J \& Guillomot M 2007 Cellular features of the extra-embryonic endoderm during elongation in the ovine conceptus. Genesis 45 709-715. (doi:10.1002/dvg.20347)

Fujiwara T, Dehart DB, Sulik KK \& Hogan BL 2002 Distinct requirements for extra-embryonic and embryonic bone morphogenetic protein 4 in the formation of the node and primitive streak and coordination of left-right asymmetry in the mouse. Development 129 4685-4696.

Gross TS \& Williams WF 1988 Bovine placental prostaglandin synthesis: principal cell synthesis as modulated by the binucleate cell. Biology of Reproduction 38 1027-1034. (doi:10.1095/biolreprod38.5. 1027)

Hambruch N, Haeger JD, Dilly M \& Pfarrer C 2010 EGF stimulates proliferation in the bovine placental trophoblast cell line F3 via Ras and MAPK. Placenta 31 67-74. (doi:10.1016/j.placenta.2009.10.011)

Hashizume K, Shimada A, Nakano H \& Takahashi T 2006 Bovine trophoblast cell culture systems: a technique to culture bovine trophoblast cells without feeder cells. Methods in Molecular Medicine 121 179-188.

Hashizume K, Ushizawa K, Patel OV, Kizaki K, Imai K, Yamada O, Nakano H \& Takahashi T 2007 Gene expression and maintenance of pregnancy in bovine: roles of trophoblastic binucleate cell-specific molecules. Reproduction, Fertility, and Development 19 79-90. (doi:10. 1071/RD06118)

Hayashi Y, Furue MK, Tanaka S, Hirose M, Wakisaka N, Danno H, Ohnuma K, Oeda S, Aihara Y, Shiota K et al. 2010 BMP4 induction of trophoblast from mouse embryonic stem cells in defined culture conditions on laminin. In Vitro Cellular \& Developmental Biology. Animal 46 416-430. (doi:10.1007/s11626-009-9266-6)

Home P, Ray S, Dutta D, Bronshteyn I, Larson M \& Paul S 2009 GATA3 is selectively expressed in the trophectoderm of peri-implantation embryo and directly regulates $\mathrm{Cdx} 2$ gene expression. Journal of Biological Chemistry 284 28729-28737. (doi:10.1074/jbc.M109.016840)

Hu D \& Cross JC 2010 Development and function of trophoblast giant cells in the rodent placenta. International Journal of Developmental Biology 54 341-354. (doi:10.1387/ijdb.082768dh)

Imai K, Tagawa M, Yoshioka H, Matoba S, Narita M, Inaba Y, Aikawa Y, Ohtake M \& Kobayashi S 2006 The efficiency of embryo production by ovum pick-up and in vitro fertilization in cattle. Journal of Reproduction and Development 52 (Supplement) 19-29.
Imakawa K, Anthony RV, Kazemi M, Marotti KR, Polites HG \& Roberts RM 1987 Interferon-like sequence of ovine trophoblast protein secreted by embryonic trophectoderm. Nature 330 377-379. (doi:10.1038/ 330377a0)

Jeckel KM, Limesand SW \& Anthony RV 2009 Specificity protein-1 and -3 trans-activate the ovine placental lactogen gene promoter. Molecular and Cellular Endocrinology 307 118-124. (doi:10.1016/j.mce.2009.04. 006)

Katagiri T, Yamaguchi A, Komaki M, Abe E, Takahashi N, Ikeda T, Rosen V, Wozney JM, Fujisawa-Sehara A \& Suda T 1994 Bone morphogenetic protein-2 converts the differentiation pathway of $\mathrm{C} 2 \mathrm{C} 12$ myoblasts into the osteoblast lineage. Journal of Cell Biology 127 1755-1766. (doi:10. 1083/jcb.127.6.1755)

Kirsch T, Nickel J \& Sebald W 2000 BMP-2 antagonists emerge from alterations in the low-affinity binding epitope for receptor BMPR-II. EMBO Journal 19 3314-3324. (doi:10.1093/emboj/19.13.3314)

Kobayashi M, Takada T, Takahashi K, Noda Y \& Torii R 2008 BMP4 induces primitive endoderm but not trophectoderm in monkey embryonic stem cells. Cloning Stem Cells 10 495-502. (doi:10.1089/ clo.2008.0030)

Koshi K, Ushizawa K, Kizaki K, Takahashi T \& Hashizume K 2011 Expression of endogenous retrovirus-like transcripts in bovine trophoblastic cells. Placenta 32 493-499. (doi:10.1016/j.placenta.2011.04.002)

Kurihara T, Kitamura K, Takaoka K \& Nakazato H 1993 Murine bone morphogenetic protein-4 gene: existence of multiple promoters and exons for the $5^{\prime}$-untranslated region. Biochemical and Biophysical Research Communications 192 1049-1056. (doi:10.1006/bbrc.1993. 1523)

Limesand SW, Jeckel KM \& Anthony RV 2004 Puralpha, a single-stranded deoxyribonucleic acid binding protein, augments placental lactogen gene transcription. Molecular Endocrinology 18 447-457. (doi:10.1210/ me.2003-0392)

Marikawa Y \& Alarcón VB 2009 Establishment of trophectoderm and inner cell mass lineages in the mouse embryo. Molecular Reproduction and Development 76 1019-1032. (doi:10.1002/mrd.21057)

Martal J, Lacroix MC, Loudes C, Saunier M \& Wintenberger-Torrès S 1979 Trophoblastin, an antiluteolytic protein present in early pregnancy in sheep. Journal of Reproduction and Fertility 56 63-73. (doi:10.1530/jrf. $0.0560063)$

Martal J, Chêne N, Camous S, Huynh L, Lantier F, Hermier P, L'Haridon R, Charpigny G, Charlier M \& Chaouat G 1997 Recent developments and potentialities for reducing embryo mortality in ruminants: the role of IFN-tau and other cytokines in early pregnancy. Reproduction, Fertility, and Development 9 355-380. (doi:10.1071/R96083)

Matamoros RA, Caamano L, Lamb SV \& Reimers TJ 1994 Estrogen production by bovine binucleate and mononucleate trophoblastic cells in vitro. Biology of Reproduction 51 486-492. (doi:10.1095/biolreprod51.3.486)

Michael DD, Wagner SK, Ocón OM, Talbot NC, Rooke JA \& Ealy AD 2006 Granulocyte-macrophage colony-stimulating-factor increases interferon-tau protein secretion in bovine trophectoderm cells. American Journal of Reproductive Immunology 56 63-67. (doi:10.1111/j.16000897.2006.00390.x)

Murohashi M, Nakamura T, Tanaka S, Ichise T, Yoshida N, Yamamoto T, Shibuya M, Schlessinger J \& Gotoh N 2010 An FGF4-FRS2alpha-Cdx2 axis in trophoblast stem cells induces Bmp4 to regulate proper growth of early mouse embryos. Stem Cells 28 113-121. (doi:10.1002/stem.247)

Nakano H, Shimada A, Imai K, Takezawa T, Takahashi T \& Hashizume K 2002 Bovine trophoblastic cell differentiation on collagen substrata: formation of binucleate cells expressing placental lactogen. Cell and Tissue Research 307 225-235. (doi:10.1007/s00441-001-0491-x)

Nakano H, Shimada A, Imai K, Takahashi T \& Hashizume K 2005 The cytoplasmic expression of E-cadherin and beta-catenin in bovine trophoblasts during binucleate cell differentiation. Placenta 26 393-401. (doi:10.1016/j.placenta.2004.08.002)

Niwa H, Toyooka Y, Shimosato D, Strumpf D, Takahashi K, Yagi R \& Rossant J 2005 Interaction between Oct3/4 and Cdx2 determines trophectoderm differentiation. Cell 123 917-929. (doi:10.1016/j.cell. 2005.08.040)

Pfarrer C, Weise S, Berisha B, Schams D, Leiser R, Hoffmann B \& Schuler G 2006 Fibroblast growth factor (FGF)-1, FGF2, FGF7 and FGF receptors 
are uniformly expressed in trophoblast giant cells during restricted trophoblast invasion in cows. Placenta 27 758-770. (doi:10.1016/j. placenta.2005.06.007)

Ravelich SR, Shelling AN, Wells DN, Peterson AJ, Lee RS, Ramachandran A \& Keelan JA 2006 Expression of TGF-beta1, TGF-beta2, TGF-beta3 and the receptors TGF-betaRI and TGF-betaRII in placentomes of artificially inseminated and nuclear transfer derived bovine pregnancies. Placenta 27 307-316. (doi:10.1016/j.placenta.2005.03.002)

Reimers TJ, Ullmann MB \& Hansel W 1985 Progesterone and prostanoid production by bovine binucleate trophoblastic cells. Biology of Reproduction 33 1227-1236. (doi:10.1095/biolreprod33.5.1227)

Sakurai T, Sakamoto A, Muroi Y, Bai H, Nagaoka K, Tamura K, Takahashi T, Hashizume K, Sakatani M, Takahashi M et al. 2009 Induction of endogenous interferon tau gene transcription by CDX2 and high acetylation in bovine nontrophoblast cells. Biology of Reproduction $\mathbf{8 0}$ 1223-1231. (doi:10.1095/biolreprod.108.073916)

Shimada A, Nakano H, Takahashi T, Imai K \& Hashizume K 2001 Isolation and characterization of a bovine blastocyst-derived trophoblastic cell line, BT-1: development of a culture system in the absence of feeder cell. Placenta 22 652-662. (doi:10.1053/plac.2001.0702)

Shimasaki S, Moore RK, Otsuka F \& Erickson GE 2004 The bone morphogenetic protein system in mammalian reproduction. Endocrine Reviews 25 72-101. (doi:10.1210/er.2003-0007)

Spencer TE, Johnson GA, Bazer FW \& Burghardt RC 2004 Implantation mechanisms: insights from the sheep. Reproduction 128 657-668. (doi:10.1530/rep.1.00398)

Spencer TE, Sandra O \& Wolf E 2008 Genes involved in conceptusendometrial interactions in ruminants: insights from reductionism and thoughts on holistic approaches. Reproduction 135 165-179. (doi:10. 1530/REP-07-0327)

Sugawara K, Kizaki K, Herath CB, Hasegawa Y \& Hashizume K 2010 Transforming growth factor beta family expression at the bovine fetomaternal interface. Reproductive Biology and Endocrinology 8120. (doi:10.1186/1477-7827-8-120)

Takahashi T, Imai K \& Hashizume K 2004 Generation and characterization of anti-leptin antisera against synthetic peptides and recombinant protein. Journal of Reproduction and Development 50 717-724. (doi:10.1262/jrd.50.717)

Talbot NC, Caperna TJ, Edwards JL, Garrett W, Wells KD \& Ealy AD 2000 Bovine blastocyst-derived trophectoderm and endoderm cell cultures: interferon tau and transferrin expression as respective in vitro markers. Biology of Reproduction 62 235-247. (doi:10.1095/biolreprod62.2.235)

Talbot NC, Powell AM, Ocón OM, Caperna TJ, Camp M, Garrett WM \& Ealy AD 2008 Comparison of the interferon-tau expression from primary trophectoderm outgrowths derived from IVP, NT, and parthenogenote bovine blastocysts. Molecular Reproduction and Development 75 299-308. (doi:10.1002/mrd.20741)
Tsampalas M, Gridelet V, Berndt S, Foidart JM, Geenen V \& Perrier d'Hauterive S 2010 Human chorionic gonadotropin: a hormone with immunological and angiogenic properties. Journal of Reproductive Immunology 85 93-98. (doi:10.1016/j.jri.2009.11.008)

Ullah Z, Lee CY, Lilly MA \& DePamphilis ML 2009 Developmentally programmed endoreduplication in animals. Cell Cycle 8 1501-1509. (doi:10.4161/cc.8.10.8325)

Ushizawa K, Takahashi T, Hosoe M, Ishiwata H, Kaneyama K, Kizaki K \& Hashizume K 2007 Global gene expression analysis and regulation of the principal genes expressed in bovine placenta in relation to the transcription factor AP-2 family. Reproductive Biology \& Endocrinology 5 17. (doi:10.1186/1477-7827-5-17)

Ushizawa K, Takahashi T, Hosoe M, Kizaki K \& Hashizume K 2009 Characterization and expression analysis of SOLD1, a novel member of the retrotransposon-derived Ly-6 superfamily, in bovine placental villi. PLOS ONE 4 e5814. (doi:10.1371/journal.pone.0005814)

Wooding FB 1992 Current topic: the synepitheliochorial placenta of ruminants: binucleate cell fusions and hormone production. Placenta 13 101-113. (doi:10.1016/0143-4004(92)90025-O)

Wu Z, Zhang W, Chen G, Cheng L, Liao J, Jia N, Gao Y, Dai H, Yuan J, Cheng L et al. 2008 Combinatorial signals of activin/nodal and bone morphogenic protein regulate the early lineage segregation of human embryonic stem cells. Journal of Biological Chemistry 283 24991-25002. (doi:10.1074/jbc.M803893200)

Xie SC, Low BG, Nagel RJ, Kramer KK, Anthony RV, Zoli AP, Beckers JF \& Roberts RM 1991 Identification of the major pregnancy-specific antigens of cattle and sheep as inactive members of the aspartic proteinase family. PNAS 88 10247-10251. (doi:10.1073/pnas.88.22.10247)

Xu RH, Chen X, Li DS, Li R, Addicks GC, Glennon C, Zwaka TP \& Thomson JA 2002 BMP4 initiates human embryonic stem cell differentiation to trophoblast. Nature Biotechnology 20 1261-1264. (doi:10.1038/nbt761)

Yamada O, Todoroki J, Kizaki K, Takahashi T, Imai K, Patel OV, Schuler LA \& Hashizume K 2002 Expression of prolactin-related protein I at the fetomaternal interface during the implantation period in cows. Reproduction 124 427-437. (doi:10.1530/rep.0.1240427)

Yuan P, Han J, Guo G, Orlov YL, Huss M, Loh YH, Yaw LP, Robson P, Lim B \& Ng HH 2009 Eset partners with Oct4 to restrict extraembryonic trophoblast lineage potential in embryonic stem cells. Genes and Development 23 2507-2520. (doi:10.1101/gad.1831909)

Zhang P, Li J, Tan Z, Wang C, Liu T, Chen L, Yong J, Jiang W, Sun X, Du L et al. 2008 Short-term BMP-4 treatment initiates mesoderm induction in human embryonic stem cells. Blood 111 1933-1941. (doi:10.1182/ blood-2007-02-074120)

Received 1 August 2011

First decision 23 August 2011

Accepted 23 August 2011 